\title{
EFFECT OF WHOLE OILSEEDS FEEDING ON PERFORMANCE AND NUTRITIVE VALUES OF DIETS OF YOUNG GROWING SAANEN GOATS
}

\author{
Efeito da alimentação de cabritos saanen em crescimento com grãos de oleaginosas \\ integrais sobre o desempenho e o valor nutritivo das rações
}

\author{
Paula Adriana Grande ${ }^{1}$, Claudete Regina Alcalde ${ }^{2}$, Luciano Soares de Lima ${ }^{1}$, \\ Maximiliane Alavarse Zambom $^{3}$, Francisco de Assis Fonseca de Macedo ${ }^{1}$
}

\begin{abstract}
Twenty-eight Saanen goat kids (16 non-castrated males and 12 females; $14.38 \pm 1.60 \mathrm{~kg}$ ) were used to evaluate the performance and nutritional value of diets. Animals were randomly allotted into a 4x2 (diets x gender) factorial arrangement. Treatments consisted of four different total mixed diets composed of oat hay, soybean meal, mineral supplement, and/or oilseeds replacing ground corn (on dry matter basis), as follows: 1) control (without oilseeds), 2) diet containing 7.9\% flaxseed, 3) diet with 7.3\% sunflower, and 4) diet containing $8.0 \%$ canola. Dry matter intake was higher for animals receiving control diet. Gender did not influence dry matter and nutrient intake. Oilseeds did not affect the average daily gain (ADG) and feed conversion (FC). Flaxseed diet showed more days in feedlot. Males showed better means of ADG, FC and days in feedlot. Diets containing oilseeds had higher values for ether extract digestibility and lower total carbohydrates than the control diet. The energetic value of diets did not alter. The inclusion of flaxseed, sunflower or canola in diets of Saanen goat kids in place ( $8 \%$ on a DM basis) corn, does not improve the performance, however these oilseeds may be used without changing the nutritional value of diets.
\end{abstract}

Index terms: Digestibility, intake, fat supply, goats, performance.

\section{RESUMO}

Com o objetivo de avaliar os efeitos do uso de grão de oleaginosas sobre o desempenho e o valor nutricional das rações, foram utilizados 28 cabritos Saanen (16 machos e 12 fêmeas; 14,38 $\pm 1,60 \mathrm{~kg}$ ) distribuídos aleatoriamente em arranjo fatorial 4x2 (rações e sexos). Os tratamentos consistiram em rações compostas por feno de aveia, milho moído, farelo de soja e suplemento mineral e/ou grãos de oleaginosas em substituição ao milho, conforme os seguintes tratamentos: 1) controle; 2) 7,9\% linhaça; 3) $7,3 \%$ de girassol; e 4) 8,0\% de canola. A ingestão de matéria seca foi maior para ração controle. Não houve diferença entre os sexos para ingestão. $\mathrm{O}$ ganho médio diário (GMD) e a conversão alimentar (CA) não foram alterados. O número de dias em confinamento (DC) foi maior dentro da ração linhaça. Os cabritos machos apresentaram melhor GMD, CA e DC. A inclusão das oleaginosas aumentou a digestibilidade do extrato etéreo e reduziu a digestibilidade dos carboidratos totais. Não foram observadas diferenças para a concentração energética das rações. A inclusão dos grãos de linhaça, girassol ou canola nas rações de cabritos Saanen, em substituição ( $8 \%$ MS) ao milho, não traz benefícios ao desempenho, no entanto, esses alimentos podem ser utilizados sem que haja alteração do valor nutricional das rações.

Termos para indexação: Digestibilidade, ingestão, suplementação lipídica, caprinos, desempenho.

\section{INTRODUCTION}

After weaning, female goats can be used in replacement herd, while males are generally intended for meat production (Shrestha; Crow, 2010). However, whether for replacement or for meat production the food intake and energy supply is a common factor at this stage of development.

In this case, the consumption of small amounts of fat can be interesting in order to increase energy intake and animal performance (Kawas, Andrade-Montemayor; $\mathrm{Lu}, 2010$ ), because these molecules play major role in energy metabolism and their oxidation results in greater release of energy compared to carbohydrates and proteins (Lehninger, 2000).

Oilseeds such as flaxseed, sunflower and canola have a high energy content, provided by combination of protein, fiber, and mainly of unsaturated fatty acids (linolenic, oleic and linoleic) which play many important functions in the animal body (Chichlowski et al., 2005; Glasser, Ferlay; Cheliard, 2008).

However, the inclusion of fat sources in ruminant diet must be done under caution because it can cause problems in rumen fermentation and, consequently, can

${ }^{1}$ Universidade Estadual do Maringá/UEM - Departamento de Zootecnia/DZO - Avenida Colombo - n. 5790 - $87020-900$ - Maringá - PR - Brasil paulagrde@gmail.com

${ }^{2}$ Universidade Estadual do Maringá/UEM - Departamento de Zootecnia/DZO - Maringá - PR - Brasil

${ }^{3}$ Universidade Estadual do Oeste do Paraná/UNIOESTE - Departamento de Zootecnia/DZO - Marechal Cândido Rondom - PR - Brasil

Received in july 16, 2013 and approved in december 23, 2013 
damage the intake and performance. The polyunsaturated fatty acids and those in non-esterified form seem to be more potent inhibitors of consumption and digestion (Benson et al., 2001).

The supply of whole oilseeds is a way to moderate the release of nutrients in the rumen and thus increase the availability in the small intestine (Dayani, Dadvar; Afsharmanesh, 2011; Zhang, Mustafa; Zhao, 2007), then it may be advantageous to performance of growing goat kids.

This work was carried out to evaluate the effects of feeding whole oilseeds (flaxseed, sunflower and canola) on performance and nutritive value diets of growing Saanen goat kids.

\section{MATERIAL AND METHODS}

This experiment was conducted at the Fazenda Experimental de Iguatemi, of the Universidade Estadual de Maringá, southern Brazil. Twenty-eight Saanen goat kids (16 non-castrated males and 12 females, averaging $14.38 \pm 1.40 \mathrm{~kg}$ of BW) were used randomly distributed in a factorial arrangement with $4 \times 2$ (diets and gender).

Animals were weaned at 60 days of age and adapted on 15 days period, where goat kids were housed in single pens fed diets composed of oat hay, ground corn and soybean meal (control diet).

Treatments consisted of four different total mixed diets (Table 1 and 2) composed of oat hay, soybean meal and mineral supplement, and/or oilseeds replacing ground corn (on dry matter basis), as follows: 1) control (without oilseeds), 2) diet containing 7.9\% flaxseed, 3) diet with 7.3\% sunflower, and 4) diet containing $8.0 \%$ canola. Diets were formulated to meet the energy and protein requirements from AFRC (1998) and were offered to animals as total mixed rations (pelleted) once a day (8:00 a.m.) based on $3.5 \% \mathrm{DM}$ of the body weight in order to provide $10 \%$ of orts.
During the experimental period, the animals were kept in single pens and had free access to water. Animals were weighed during fasting period $(16 \mathrm{~h})$ at the beginning of the experiment and once every two weeks to be adjusted to the offered feeding and to determine the average daily gain. Days in feedlot were also evaluated, which consisted on the time required to reach slaughter weight $( \pm 30.0 \mathrm{~kg})$, started to be counted from the beginning of the trial. At the end of experimental period males were slaughtered to carcass evaluation and females were used to herd replacement.

To predict fecal output and digestibility, fecal grab samples were collected for five consecutive days (from $30^{\text {th }}$ day) at intervals of 26 hours, and then stored at $-20^{\circ}$ $\mathrm{C}$ until use. These samples were pooled by animal after drying $\left(55^{\circ} \mathrm{C}\right)$ for subsequent analysis.

Indigestible NDF (iNDF) was used as an internal marker to estimate fecal output and apparent nutrient digestibility. For iNDF analysis, $0.5 \mathrm{~g}(1 \mathrm{~mm})$ of period fecal, orts and food samples were in situ incubated (144 h) in the rumen goat within nylon bags $\left(\right.$ F57Ankon ${ }^{\circledR}$ ) followed by neutral detergent analysis using Ankom ${ }^{200}$ (Ankom Technology Corp., Fairport, NY) filter bag technique.

Samples (feeds, orts and feces) were oven-dried $\left(55^{\circ} \mathrm{C}\right.$ for $\left.72 \mathrm{~h}\right)$, then ground in cutter type mill with a $1 \mathrm{~mm}$ screen. Dry matter was evaluated according to method no. 934.01 of AOAC (1998). Organic matter was determined by combustion in a muffle furnace according to AOAC (1998) method no. 942.05. Total nitrogen (TN) determination used a Tecnal TE-036/1 (Tecnal, Piracicaba, São Paulo, Brazil) following method no. 988.05 of the AOAC (1998)and crude protein $(\mathrm{CP})$ was estimated as TN x 6.25. Ether extract in diets was determined with Tecnal TE-044/1 according to the method no. 920.39 of AOAC (1998). The concentration of NDF was determined using Ankom ${ }^{200}$ (Ankom Technology Corp., Fairport, NY) filter bag technique. The ADF content was determined according to AOAC (1998) method no.973.18.

Table 1 - Chemical composition of ingredients.

\begin{tabular}{lcccccc}
\hline \multirow{2}{*}{ Item } & \multicolumn{7}{c}{ Ingredient } \\
\cline { 2 - 7 } & Oat hay & Soybean meal & Ground corn & Flaxseed & Sunflower & Canola \\
\hline Dry matter (\%) & 91.15 & 89.41 & 92.42 & 93.15 & 94.37 & 91.88 \\
Organic matter (\%DM) & 98.84 & 93.33 & 98.89 & 96.99 & 98.37 & 97.00 \\
Crudeprotein (\%DM) & 15.85 & 49.56 & 8.68 & 22.41 & 17.96 & 22.75 \\
Ether extract (\%DM) & 1.45 & 2.10 & 3.29 & 26.96 & 40.65 & 36.21 \\
Neutral detergent fiber (\%DM) & 50.62 & 14.85 & 11.34 & 40.52 & 31.32 & 27.45 \\
Acid detergent fiber (\%DM) & 42.50 & 10.32 & 3.92 & 26.95 & 20.89 & 20.98 \\
\hline
\end{tabular}

Ciênc. Agrotec., Lavras, v.38, n. 2, p.181-187, mar./abr., 2014 
Table 2 - Ingredients and chemical composition of experimental diets.

\begin{tabular}{lcccc}
\hline \multirow{2}{*}{ Item } & \multicolumn{3}{c}{ Diet } \\
\cline { 2 - 5 } & Control & Flaxseed & Sunflower & Canola \\
\hline Oat hay (\%) & 30.00 & 32.95 & 33.08 & 30.76 \\
Soybean meal (\%) & 19.65 & 15.75 & 17.77 & 16.88 \\
Ground corn (\%) & 47.37 & 40.41 & 38.80 & 41.33 \\
Flaxseed (\%) & - & 7.87 & - & - \\
Sunflower seed (\%) & - & - & 7.29 & - \\
Canola seed (\%) & - & - & - & 8.00 \\
Mineral supplement ${ }^{1}(\%)$ & 3.00 & 3.00 & 3.00 & 3.00 \\
\hline Dry matter (\%) & 89.13 & 89.16 & 89.00 & 88.16 \\
Organic matter (\%DM) & 94.88 & 93.94 & 94.05 & 94.86 \\
Crude protein (\%DM) & 16.45 & 18.59 & 17.69 & 18.02 \\
Ether extract (\%DM) & 1.62 & 2.96 & 3.16 & 3.98 \\
Total carbohydrates (\%DM) & 76.81 & 72.39 & 73.30 & 72.86 \\
Nonfiber carbohydrates (\%DM) & 45.96 & 38.33 & 36.32 & 40.32 \\
Neutral detergent fiber (\%DM) & 30.85 & 34.06 & 36.98 & 32.54 \\
Metabolizable energy (Mcal/kg DM) & 2.64 & 2.59 & 2.61 & 2.65 \\
\hline Chy & & & & \\
\hline
\end{tabular}

${ }^{\mathrm{I}}$ Chemical composition (per kg of product): A vitamin - 135,000 UI; D3 vitamin - 68,000 UI; E vitamin - 450 UI; Ca - 240 g; P - 71 g; K - 28.20 g; S -20 g; Mg - 20g; Cu - 400 mg; Co - 30 mg; Cr - 10 mg; Fe - 2,500 mg; I - 40 mg; Mn - 1,350 mg; Se - 15 mg; Zn $-1,700 \mathrm{mg}$; F - $710 \mathrm{mg}$ (max); Citric acid (2\%) solubility of phosphorus 95\% (min) (Commercial product).

${ }^{2}$ Calculated using published values of feed ingredients (NRC, 2001).

Total carbohydrates (TC) and total digestible nutrients (TDN) were estimated according to equations described by Sniffen et al. (1992): TC $(\%)=100-(\% \mathrm{CP}$ $+\% \mathrm{EE}+\%$ ash $)$ and $\mathrm{TDN}=\mathrm{dCP}+(2.25 \mathrm{x} \mathrm{dEE})+\mathrm{dTC}$, where $\mathrm{dCP}=$ digestible crude protein, $\mathrm{dEE}=$ digestible ether extract and $\mathrm{dTC}=$ digestible total carbohydrates.

The data obtained were analyzed using variance analysis utilizing SAEG system (Universidade Federal de Viçosa - UFV, 2007) with the following general model: $Y_{\mathrm{ijk}}=$ $\mu+D_{i}+G_{j}+D_{i j}+e_{i j k}$; where: $Y_{i j k}=$ the dependent variable, $\mu=$ overall mean; $\mathrm{D}_{\mathrm{i}}=$ effect of diet $i, i=$ control, flaxseed, sunflower or canola; $\mathrm{G}_{\mathrm{j}}=$ effect of gender $j, j=1$ for male and $j=2$ for female; $\mathrm{DG}_{\mathrm{ij}}=$ interaction between diet $i$ and gender $j$; $\mathrm{e}_{\mathrm{ijk}}=$ random residual error. Data of digestibility were analyzed using variance analysis with the following general model: $\mathrm{Y}_{\mathrm{ij}}=$ $\mu+D_{i}+e_{i j}$; where: $Y_{i j}=$ the dependent variable, $\mu=$ overall mean; $\mathrm{D}_{\mathrm{i}}=$ effect of diet $i, i=$ control, flaxseed, sunflower or canola; $\mathrm{e}_{\mathrm{ij}}=$ random residual error.

\section{RESULTS AND DISCUSSION}

Dry matter intake $(\mathrm{kg} / \mathrm{d})$ was higher $(\mathrm{P}<0.05)$ for animals receiving control diet. However, this is not reflected indifferences $(\mathrm{P}>0.05)$ in intake of nutrients (Table 3). Reductions in consumption due to fat supply are generally associated with the ether extract content. Silva et al., (2010) also reported reduction for dry matter intake when lactating goats were fed with oilseeds-diets.

However, in the current experiment, the inclusion of oilseeds provided ether extract content of $3.37 \%$ on average, which is not considered harmful to feed intake. Thus, this observation seems to be related to the characteristic of fat in the diet. Flaxseed, sunflower and canola seeds are rich sources of linolenic acid (C18: 3), linoleic (C18: 2) and oleic (C18: 1), respectively (Chichlowski et al., 2005; Glasser et al., 2008).

The duodenal availability of fatty acids can decreases feed intake (Benson et al., 2001; Bremmer et al., 1998) and, in the current experiment, the supply of fat in protected form (whole seeds) may have promoted greater release of duodenal fatty acids and caused decrease in feed intake in oilseeds diets compared to control diet. Another point to be considered is the possibility of interference of oilseeds in the flavor of diets, which can be a selection factor in goat kids (De Rosa et al., 2002). 
Table 3 - Intake of dry matter and of nutrients in Saanen goat kids fed diets with whole oilseeds.

\begin{tabular}{|c|c|c|c|c|c|c|}
\hline \multirow{2}{*}{ Item } & \multicolumn{4}{|c|}{ Diets } & \multirow[b]{2}{*}{ Mean } & \multirow[b]{2}{*}{$\mathrm{CV}$} \\
\hline & Control & Flaxseed & Sunflower & Canola & & \\
\hline \multicolumn{7}{|c|}{ Dry matter intake $(\mathrm{kg} / \mathrm{d})$} \\
\hline Male & 0.87 & 0.80 & 0.79 & 0.72 & 0.80 & \\
\hline Female & 0.88 & 0.83 & 0.80 & 0.79 & 0.81 & 8.06 \\
\hline Mean & $0.87 \mathrm{a}$ & $0.81 \mathrm{~b}$ & $0.76 b$ & $0.75 b$ & - & \\
\hline \multicolumn{7}{|c|}{ Dry matter intake (\% of BW) } \\
\hline Male & 3.84 & 3.45 & 3.40 & 3.30 & 3.49 & \\
\hline Female & 3.99 & 3.89 & 3.89 & 3.65 & 3.85 & 12.20 \\
\hline Mean & 3.85 & 3.62 & 3.36 & 3.42 & 3.56 & \\
\hline \multicolumn{7}{|c|}{ Organic matter intake $(\mathrm{kg} / \mathrm{d})$} \\
\hline Male & 0.69 & 0.66 & 0.64 & 0.62 & 0.65 & \\
\hline Female & 0.70 & 0.72 & 0.69 & 0.65 & 0.69 & 4.26 \\
\hline Mean & 0.69 & 0.69 & 0.66 & 0.63 & 0.66 & \\
\hline \multicolumn{7}{|c|}{ Crude protein intake $(\mathrm{kg} / \mathrm{d})$} \\
\hline Male & 0.14 & 0.13 & 0.14 & 0.12 & 0.13 & \\
\hline Female & 0.14 & 0.13 & 0.14 & 0.13 & 0.13 & 6.31 \\
\hline Mean & 0.14 & 0.13 & 0.14 & 0.12 & 0.13 & \\
\hline \multicolumn{7}{|c|}{ Ether extract intake $(\mathrm{kg} / \mathrm{d})$} \\
\hline Male & 0.02 & 0.03 & 0.03 & 0.03 & 0.03 & \\
\hline Female & 0.01 & 0.03 & 0.03 & 0.03 & 0.03 & 8.98 \\
\hline Mean & 0.02 & 0.03 & 0.03 & 0.03 & 0.03 & \\
\hline \multicolumn{7}{|c|}{ Neutral detergent fiber $(\mathrm{kg} / \mathrm{d})$} \\
\hline Male & 0.32 & 0.34 & 0.31 & 0.33 & 0.31 & \\
\hline Female & 0.32 & 0.34 & 0.30 & 0.28 & 0.31 & 8.98 \\
\hline Mean & 0.32 & 0.34 & 0.31 & 0.27 & 0.31 & \\
\hline
\end{tabular}

Means with different superscripts in a row differ $(\mathrm{P}<0.05)$ by Tukey test.

There was no difference $(\mathrm{P}>0.05)$ between males and females for dry matter and nutrient intake. In extensive systems, differences in intake between males and females are always expected due to the preferences and food selection skills related to gender (Dove, 2010). However, the current experiment was performed in feedlot system, providing total mixed diets in the feeders. It probably contributed to the similarity between males and females intakes. Total mixed diets offered in pellets also may have influenced this process by difficulty in feed selecting. Furthermore, goats preferred pelleted diets over those offered as a meal or liquid (Bateman et al., 2004).

Oilseeds did not affect $(\mathrm{P}>0.05)$ the average daily gain and feed conversion (Table 4). On the other hand, flaxseed diet showed higher $(\mathrm{P}<0.05)$ mean.

Gender differences were observed $(\mathrm{P}<0.05)$ to average daily gain, feed conversion and days in feedlot (Table 4), where males showed higher means. It agrees with the normal growth curve by males and females after weaning(SOLAIMAN, 2010), because at this stage, males usually grow about $30 \%$ faster than females (Mcmillin, 
2010). In the current experiment, the observed difference was smaller (about 17\%) which is related to the system (confinement) and form of offering rations (pelleted) that probably led to the reduction of this difference.

During the evaluation of digestibility similar effects of oilseeds on dry matter intake were observed, where control diet showed higher $(\mathrm{P}<0.05)$ value (Table 5). However these differences were not observed in nutrients (CP, EE, TC and NDF) intake.

The inclusion of oilseeds in the diets did not affect $(\mathrm{P}>0.05)$ digestibility of dry matter, organic matter, crude protein and neutral detergent fiber and total digestible nutrients. However, differences were observed $(\mathrm{P}<0.05)$ for the digestibility of ether extract and total carbohydrates, where diets containing oilseeds had higher values for ether extract digestibility and lower total carbohydrates than the control diet (Table 5).

The higher digestibility of the ether extract provided by the oilseeds is related to a direct effect of increased intake of this nutrient as a result of the composition of the diets. In addition, oilseeds are sources of unsaturated fatty acids which, usually, have better digestibility compared to saturated fatty acids (Palmquist; Mattos, 2006).

The control diet allowed higher $(\mathrm{P}<0.05)$ digestibility of total carbohydrates is related to the greater non-fibrous carbohydrates content in this diet. Non-fiber carbohydrates are more digestible than the fibrous carbohydrates and the highest non-fiber carbohydrate content of control diet is a result of increased participation of corn in its final composition (Table 2). It offsets the additional energy from fat in oilseeds providing diets with similar energy value (Table 6).

Table 4 - Performance of Saanen goat kids fed diets with whole oilseeds.

\begin{tabular}{|c|c|c|c|c|c|c|}
\hline \multirow{2}{*}{ Item } & \multicolumn{4}{|c|}{ Diets } & \multirow[b]{2}{*}{ Mean } & \multirow[b]{2}{*}{$\mathrm{CV}$} \\
\hline & Control & Flaxseed & Sunflower & Canola & & \\
\hline \multicolumn{7}{|c|}{ Initial body weight (kg) } \\
\hline Male & 14.81 & 15.47 & 15.67 & 14.05 & 15.16 & \multirow{2}{*}{-} \\
\hline Female & 13.96 & 13.10 & 12.80 & 13.56 & 13.35 & \\
\hline \multicolumn{7}{|c|}{ Final body weight $(\mathrm{kg})$} \\
\hline Male & 30.55 & 30.92 & 30.75 & 30.22 & 30.61 & \\
\hline Female & 30.06 & 29.56 & 28.26 & 29.70 & 29.40 & - \\
\hline Mean & 30.34 & 30.34 & 29.68 & 30.00 & 30.09 & \\
\hline \multicolumn{7}{|c|}{ Average daily gain $(\mathrm{kg})$} \\
\hline Male & 0.24 & 0.21 & 0.23 & 0.24 & $0.23 \mathrm{~A}$ & \\
\hline Female & 0.22 & 0.18 & 0.19 & 0.20 & $0.20 \mathrm{~B}$ & 13.37 \\
\hline Mean & 0.23 & 0.20 & 0.21 & 0.22 & - & \\
\hline \multicolumn{7}{|c|}{ Feed conversion (kg DM/ kg gain) } \\
\hline Male & 3.33 & 3.93 & 3.14 & 2.89 & $3.32 \mathrm{~A}$ & \\
\hline Female & 3.70 & 4.34 & 3.56 & 3.64 & $3.81 \mathrm{~B}$ & 15.34 \\
\hline Mean & 3.49 & 4.10 & 3.32 & 3.21 & 3.53 & \\
\hline \multicolumn{7}{|c|}{ Days in feedlot } \\
\hline Male & 61.75 & 74.00 & 64.00 & 65.75 & $66.37 \mathrm{~A}$ & \\
\hline Female & 71.00 & 90.00 & 80.00 & 80.00 & $80.37 \mathrm{~B}$ & 14.80 \\
\hline Mean & $66.38 \mathrm{a}$ & $82.00 \mathrm{~b}$ & $72.00 \mathrm{a}$ & $72.85^{\mathrm{a}}$ & - & \\
\hline
\end{tabular}

Means with different superscripts in a row or column $\operatorname{differ}(\mathrm{P}<0.05)$ by Tukey test. 
Table 5 - Intake, digestibility of diets with whole oilseeds in goat kids.

\begin{tabular}{|c|c|c|c|c|c|}
\hline \multirow[b]{2}{*}{ Item } & \multicolumn{4}{|c|}{ Diets } & \multirow[b]{2}{*}{$\mathrm{CV}$} \\
\hline & Control & Flaxseed & Sunflower & Canola & \\
\hline Body weight (kg) & 25.00 & 26.70 & 24.54 & 27.00 & \\
\hline \multicolumn{6}{|c|}{ Intake $(\mathrm{kg} / \mathrm{d})$} \\
\hline Dry matter & $0.82 \mathrm{a}$ & $0.73 b$ & $0.73 b$ & $0.74 b$ & 5.03 \\
\hline Organic matter & $0.87 \mathrm{a}$ & $0.84 \mathrm{a}$ & $0.76 b$ & $0.82 b$ & 8.06 \\
\hline Crude protein & 0.14 & 0.14 & 0.15 & 0.13 & 6.31 \\
\hline Ether extract & 0.01 & 0.03 & 0.03 & 0.04 & 34.43 \\
\hline Total carbohydrates & 0.74 & 0.63 & 0.64 & 0.65 & 15.16 \\
\hline Neutral detergent fiber & 0.32 & 0.34 & 0.31 & 0.27 & 8.98 \\
\hline \multicolumn{6}{|c|}{ Digestibility (\%) } \\
\hline Dry matter & 62.94 & 62.19 & 61.55 & 63.31 & 3.50 \\
\hline Organic matter & 64.36 & 63.92 & 64.81 & 63.99 & 7.96 \\
\hline Crude protein & 69.20 & 70.38 & 70.98 & 70.61 & 2.73 \\
\hline Ether extract & $82.20 \mathrm{~b}$ & $90.78 \mathrm{a}$ & $92.19 \mathrm{a}$ & $94.40 \mathrm{a}$ & 25.82 \\
\hline Total carbohydrates & $78.25 \mathrm{a}$ & $70.49 \mathrm{~b}$ & $68.65 b$ & $71.02 b$ & 4.81 \\
\hline Neutral detergent fiber & 57.00 & 56.99 & 55.34 & 57.12 & 5.04 \\
\hline
\end{tabular}

Means with different superscripts in a row differ $(\mathrm{P}<0.05)$ by Tukey test.

Table 6 - Energetic value of experimental diets in Saanen goat kids.

\begin{tabular}{|c|c|c|c|c|c|c|}
\hline \multirow[b]{2}{*}{ Item } & \multicolumn{4}{|c|}{ Diet } & \multirow[b]{2}{*}{ Mean } & \multirow[b]{2}{*}{$\mathrm{CV}$} \\
\hline & Control & Flaxseed & Sunflower & Canola & & \\
\hline Total digestible nutrients $(\% \mathrm{DM})^{1}$ & 60.32 & 58.45 & 57.12 & 60.89 & 53.96 & 9.79 \\
\hline Digestible energy $(\mathrm{Mcal} / \mathrm{kg} \text { of } \mathrm{DM})^{2}$ & 2.66 & 2.58 & 2.52 & 2.69 & 2.61 & 9.79 \\
\hline Metabolizable energy $(\mathrm{Mcal} / \mathrm{kg} \text { of } \mathrm{DM})^{3}$ & 2.18 & 2.11 & 2.07 & 2.20 & 2.14 & 9.79 \\
\hline
\end{tabular}

\section{CONCLUSION}

The inclusion of the whole flaxseed, sunflower and canola ( $8 \%$ on DM basis) in diets of Saanen goat kids replacing ( $8 \%$ on a DM basis) corn, no improves the performance, however these oilseeds may be used without changing the nutritional value of diets.

\section{REFERENCES}

\section{AGRICULTURAL AND FOOD RESEARCH} COUNCIL - AFRC. Technical committee on response to nutrients. The nutrition of goats. Wallingford, CT.: CAB International, 1998. 118p.
ASSOCIATION OF OFFICIAL AGRICULTURAL CHEMISTS - AOAC. Official Methods of Analysis. 16.ed. Gaithersburg, M.P.: Association of Official Analytical Chemists, 1998.

BATEMAN, H.G.; WHITE et al. Case study: goat preference for concentrates or forages is influenced by physical and chemical characteristics of the Feed. The Professional Animal Scientist, 20:98-204, 2004.

BENSON, J.A.; et al. Effects of abomasal infusion of long-chain fatty acids on intake, feeding behavior and milk production in dairy cows. Journal of Dairy Science, 84:1182-1191, 2001. 
BREMMER, D.R. et al. Effects of chain length and unsaturation of fatty acid mixtures infused into the abomasum of lactating dairy cows. Journal of Dairy Science, 81:176-188, 1998.

CHICHLOWSKI, M.W.; et al. Altering the fatty acids in milk fat by including canola seed in dairy cattle diets. Journal of Dairy Science, 88:3084-3094, 2005.

DAYANI, O.; DADVAR, P.; AFSHARMANESH, M. Effect of dietary whole cottonseed and crude protein level on blood parameters and performance of fattening lambs. Small Ruminant Research, 97:48-54, 2011.

DE ROSA, G.; MOIO, L.; et al. Influence of flavor on goat feeding preferences. Journal of Chemical Ecology, 28:269-281, 2002.

DOVE, H. Ingestive Behavior, Diet Selection, and Feed Intake In: SOLAIMAN, S.G. Goat Science and Production. Ames, Iowa: Wiley-Blackwell, 2010. p.179-192.

GLASSER, F.; FERLAY, A.; CHILLIARD, Y. Oilseed lipid supplements and fatty acid composition of cow milk: a meta-analysis. Journal of Dairy Science, 91:4687-4703, 2008.

KAWAS, J.R.; ANDRADE-MONTEMAYOR, H.; LU, C.D. Strategic nutrient supplementation of free-ranging goats. Small Ruminant Research, 89(2-3):p.234-243, 2010.

LEHNINGER, A.L. Biochemistry. The molecular basis of cell structure and function. New York: Oxford University Press, 2000. 833p.

MCMILLIN, K.W. Meat Production and Quality In: SANDRA GOLPASHINI SOLAIMAN. Goat science and production. Ames, Iowa: Wiley-Blackwell, 2010. p.255-273.
NATIONAL RESEARCH COUNCIL. Nutrients requirements of beef cattle. 7.ed. Washington, D.C.: The National Academies Press, 1996. 242p.

\section{NATIONAL RESEARCH COUNCIL. Nutrients} requirements of dairy cattle. 7.ed. Washington, D.C.: The National Academies Press, 2001. 381p.

PALMQUIST, D.L.; MATTOS, W.R.S. Metabolismo de lipídeos. In: BERCHIELLI, T. T.. Nutrição de ruminantes. Jaboticabal: FUNEP, 2006. p.287-310.

SHRESTHA, J.N.B.; CROW, G.H. Breeding and Genetics. In: SOLAIMAN, S. G. Goat Science and Production. Ames, Iowa: Wiley Blackwell 2010. p.5576.

SILVA, G.D.L.S. et al. Efeito da inclusão de fontes lipídicas na dieta de cabras em lactação sobre os parâmetros sanguíneos. Ciência e Agrotecnologia, 34(1):233-239, 2010.

SNIFFEN, C.J.; et al., A net carbohydrate and protein system for evaluating cattle diets: II. Carbohydrate and protein availability. Journal of Animal Science, 70:3562-3577, 1992.

SOLAIMAN, D.; ASHBY, R.D. The influence of increasing media methanolconcentratio nonsophorolipidbiosynthesisfromglycerolbasedfeedstocks. Biotechnology Letters, 32:14291437, 2010.

UNIVERSIDADE FEDERAL DE VIÇOSA - UFV. Sistema de análises estatísticas e genéticas - SAEG. Versão 9.1. Viçosa, MG, 2007, 150p.

ZHANG, R.H.; MUSTAFA, A.F.; ZHAO, X. Effects of feeding oilseeds on nutrient utilization by lactating ewes. Small Ruminant Research, 67(2-3):307-311, 2007. 